\title{
Management of Patent Vitellointestinal Duct in Infants
}

\author{
Rajendra K. Ghritlaharey ${ }^{1}$ \\ 1Department of Paediatric Surgery, Gandhi Medical College and \\ Associated Kamla Nehru and Hamidia Hospital, Bhopal, Madhya \\ Pradesh, India
}

Ann Natl Acad Med Sci (India) 2021;57:94-99.

\begin{abstract}
Address for correspondence Rajendra K. Ghritlaharey, MS, MCh, FAIS, MAMS, DLitt, Department of Paediatric Surgery, Gandhi Medical College and Associated Kamla Nehru and Hamidia Hospitals, Bhopal 462001, Madhya Pradesh, India (e-mail: drrajendrak1@rediffmail.com).
\end{abstract}

\begin{abstract}
Keywords

- infants

- intestinal obstruction

- omphalomesen-

teric duct

- patent vitelline duct

- patent

vitellointestinal duct

- vitelline duct

- vitellointestinal duct
\end{abstract}

Objectives This study was undertaken to investigate and review the clinical presentation, surgical procedures executed, and the final outcome of infants managed for the patent vitellointestinal duct.

Materials and Methods This is a single-institution, retrospective study and included infants who were operated for the patent vitellointestinal duct. This study was conducted at author's Department of Paediatric Surgery during the last 20 years; from January 1, 2000 to December 31, 2019.

Results A total of 24 infants were operated for the patent vitellointestinal duct during the study period and comprised $20(83.3 \%)$ boys and $4(16.6 \%)$ girls. The age of infants ranged from 7 days to 10 months, with a mean of $88.41 \pm 64.9$ days. Twenty-three $(95.8 \%)$ infants were operated within 6 months of the age, $17(70.8 \%)$ of them were operated within 3 months of the age. Only one (4.1\%) infant was operated at the age of 10 months. Among 24 infants, 13 (54.1\%) were presented with features suggestive of acute intestinal obstruction and remaining 11 (45.8\%) were presented with fecal discharges through the umbilicus without intestinal obstruction. Among 13 infants who presented with acute intestinal obstruction, 12 had prolapsed bowel and 6 of them also had gangrenous bowel. Operative procedures were executed $(n=24)$ in the following order of frequency: (1) resection of patent vitellointestinal duct, wide wedge resection of ileum, and ileal repair ( $n=13,54.1 \%)$; (2) resection of patent vitellointestinal duct, small segment of ileum, and ileoileal anastomosis ( $n=9,37.5 \%)$; and (3) resection of patent vitellointestinal duct, segment of ileum, and an ileostomy ( $n=2$, $8.33 \%$ ). Postoperatively, two (8.3\%) infants developed anastomotic leak and peritonitis one each, later on, both of them died.

Conclusion Patent vitellointestinal duct not only present with fecal discharges through the umbilicus but half of the infants presented with prolapsed bowel and with features of acute small bowel obstruction. Delay in seeking treatment for such cases was associated with considerable morbidity and mortality and therefore the patent vitellointestinal duct should be excised at the earliest. published online February 17, 2021
DOI https://doi.org/

$10.1055 / \mathrm{s}-0041-1722836$ ISSN 0379-038X.

\footnotetext{
(C) 2021. National Academy of Medical Sciences (India).

This is an open access article published by Thieme under the terms of the Creative Commons Attribution-NonDerivative-NonCommercial-License, permitting copying and reproduction so long as the original work is given appropriate credit. Contents may not be used for commercial purposes, or adapted, remixed, transformed or built upon. (https://creativecommons.org/licenses/by-nc-nd/4.0/).

Thieme Medical and Scientific Publishers Pvt. Ltd. A-12, 2nd Floor, Sector 2, Noida-201301 UP, India
} 


\section{Introduction}

Persistent or patent vitellointestinal duct occurred due to the complete failure of the regression of the vitellointestinal duct and reported in about $15 \%$ of all the vitellointestinal duct anomalies. ${ }^{1-3}$ Meckel's diverticulum is the commonest among the vitellointestinal duct anomalies and also a most common congenital malformation of the gastrointestinal tract. ${ }^{4,5}$ Most of the cases of patent vitellointestinal duct clinically present during the infancy but also reported after infancy and in older children. ${ }^{6-8}$ Patent vitellointestinal ducts is extremely rare in adults but have been reported in literature. ${ }^{9}$ Diagnosis is obvious in most of the cases due to the presence of omphaloenteric fistula/ patent vitellointestinal duct and fecal discharges through the umbilicus. Standard therapy for the patent vitellointestinal duct is surgical resection of the patent duct with or without resection of adjacent small segment of ileum. ${ }^{6-8,10}$ Present study comprised of the 24 infants who were operated for the patent vitellointestinal duct, with a brief review of the literature. To the best of author's knowledge, this is the largest series on the management of the patent vitellointestinal duct, exclusively in infants.

\section{Materials and Methods}

This is a single-institution, retrospective study and included infants who were operated for the patent vitellointestinal duct. This study was conducted as author's department of pediatric surgery during the last 20 years from January 1, 2000 to December 31, 2019. Medical records of all the 24 infants were reviewed for their age, sex, clinical presentation, surgical procedures executed, postoperative major complications, and the final outcome of the infants who were operated for the patent vitellointestinal duct.

\section{Results}

Twenty-four infants were operated for the patent vitellointestinal duct during the study period. Demographic details of above 24 infants are provided in - Table 1. Age distribution of the above infants is provided in - Fig. 1. The mean age of infants was $88.41 \pm 64.9$ days, ranged from 7 days to 10 months. Clinically $11(45.8 \%)$ infants presented with fecal discharges through the umbilicus without intestinal obstruction (-Fig. 2A, B) and 13 (54.1\%) infants were presented with features suggestive of acute small intestinal obstruction. Prolapsed bowel was observed in 12 of the infants ( - Fig. $\mathbf{3 A - C}$ ). Operative findings of above infants are detailed in - Fig. 4. Operative procedures executed for above infants are detailed in the - Fig. 5. Right transverse supraumbilical incision and subumbilical incision were selected in equal number of infants. Postoperatively, two (8.3\%) infants developed anastomotic leak and peritonitis, one each. Infant who developed anastomotic leak required reexploration. Later on, both of the above infants died during the course of management.

\section{Discussion}

In the early weeks of fetal life the midgut loop has a wide communication with the yolk sac known as vitellointestinal duct. The vitellointestinal duct is also named as vitelline duct, omphaloenteric duct, omphalomesenteric duct, omphaloileal fistula, and umbilicointestinal fistula. It appears at the end of the fourth week, and normally disintegrates at 8 to 10 weeks of intrauterine life..$^{1-3}$ The obliteration process of the vitellointestinal duct begins at the umbilical end of the duct and extends toward the intestine. ${ }^{11}$ The intestinal end of the vitellointestinal duct persists most frequently in the form of Meckel's diverticulum. 3,4,11

Literature relating to the patent vitellointestinal duct are scanty, and the exact incidence is not known. At the Chicago Lying-In Hospital, there were 30,000 births over a period of 10 years (1937-1947). Among above 30,000 births, only two infants had complete patency of the omphalomesenteric duct, accounted for 1:15,000 (0.0066\%) hospital births. ${ }^{12}$ At the St. Luke's Hospital in Cleveland, there were 31,975 births over a period of 21 years, only two babies were born with complete patency of the omphalomesenteric duct, accounted for approximately $1: 16,000(0.0062 \%)$ hospital births. ${ }^{12}$

The patent vitellointestinal ducts occurred more frequently in infants and also documented more in male as compared to females. In a retrospective analysis of 16 symptomatic cases of vitellointestinal duct anomalies, 9 were patent vitellointestinal duct, all of them were infants, and 8 of them were boy. ${ }^{7}$ In a retrospective review of 18 children of symptomatic vitelline duct anomalies over a period of 22 years, authors recorded 12 cases of patent vitelline duct. ${ }^{8}$ In another review of 36 neonates with vitelline duct pathologies, there were 11 cases of patent vitelline duct, and authors also observed male preponderance as $10: 1 .{ }^{10}$ In analysis of 73 cases of symptomatic patent vitellointestinal duct anomalies, there were only 5 cases of patent vitellointestinal duct, and all of them were male infants. ${ }^{11}$ Kittle et al also documented patent vitellointestinal duct 4.4 times more in males than in females. ${ }^{12}$ In a review of 72 cases relating to the vitelline duct anomalies, there were 6 cases of patent vitellointestinal duct. ${ }^{13}$ In a series of 66 cases of anomalies relating to the vitelline duct in infants and children, authors found 20 cases of patent vitelline duct, and they also documented the above anomaly more in male. ${ }^{14}$ Amongst 217 children relating to the vitelline duct anomalies, there were only 4 cases relating to the patent vitelline duct, and all of them were neonates. ${ }^{15}$ Present study on patent vitellointestinal ducts included only infants. Among 24 infants, 23 (95.8\%) were 7 days to 6 months of age, and only one boy was of the age of 10 months. This study documented 20 males, with a male-to-female ration of $5: 1$, and further support that the above anomaly is more frequent in male.

Clinical presentation varies from the discharges of mucus, flatus, and feces through the umbilicus to the acute small intestinal obstruction. ${ }^{6-8}$ Prolapse of the bowel (ileum) through the umbilicus/patent vitellointestinal duct is the gravest complication relating to the untreated cases, and reported in as many as $50 \%$ of the cases. ${ }^{6,11,16,17}$ 
Table 1 Demographics of infants operated for the patent vitellointestinal duct $(n=24)$

\begin{tabular}{|c|c|c|c|c|c|c|}
\hline $\begin{array}{l}\text { Serial } \\
\text { no. }\end{array}$ & Age & Sex & $\begin{array}{l}\text { Date of } \\
\text { operation }\end{array}$ & $\begin{array}{l}\text { Presentation and clinical } \\
\text { examination }\end{array}$ & Operative procedures executed & Result \\
\hline 1. & $3 \mathrm{mo}$ & Male & $\begin{array}{l}\text { February 24, } \\
2001\end{array}$ & Fecal discharges through umbilicus & $\begin{array}{l}\text { Resection of patent vitellointestinal duct, } \\
\text { small segment of ileum, and ileoileal } \\
\text { anastomosis }\end{array}$ & Well \\
\hline 2. & $3 \mathrm{mo}$ & Male & $\begin{array}{l}\text { March 31, } \\
2001\end{array}$ & $\begin{array}{l}\text { Intestinal obstruction } \\
\text { Bowel prolapse: yes } \\
\text { bowel gangrene: yes }\end{array}$ & $\begin{array}{l}\text { Resection of patent vitellointestinal duct, } \\
\text { small segment of ileum, and ileoileal } \\
\text { anastomosis }\end{array}$ & Well \\
\hline 3. & $2 \mathrm{mo}$ & Female & $\begin{array}{l}\text { July } 19, \\
2001\end{array}$ & $\begin{array}{l}\text { Intestinal obstruction } \\
\text { Bowel prolapse: yes } \\
\text { bowel gangrene: yes }\end{array}$ & $\begin{array}{l}\text { Resection of patent vitellointestinal duct, } \\
\text { small segment of ileum, and ileoileal } \\
\text { anastomosis }\end{array}$ & Well \\
\hline 4. & $3 \mathrm{mo}$ & Male & $\begin{array}{l}\text { September } \\
11,2003\end{array}$ & Fecal discharges through umbilicus & $\begin{array}{l}\text { Resection of patent vitellointestinal duct, } \\
\text { small segment of ileum, and ileoileal } \\
\text { anastomosis }\end{array}$ & Well \\
\hline 5. & $6 \mathrm{mo}$ & Male & $\begin{array}{l}\text { May 25, } \\
2004\end{array}$ & Fecal discharges through umbilicus & $\begin{array}{l}\text { Resection of patent vitellointestinal duct, } \\
\text { wide wedge resection of ileum and ileal } \\
\text { repair }\end{array}$ & Well \\
\hline 6. & $3 \mathrm{mo}$ & Male & $\begin{array}{l}\text { September } \\
05,2004\end{array}$ & $\begin{array}{l}\text { Intestinal obstruction } \\
\text { Bowel prolapse: yes } \\
\text { Bowel gangrene: yes }\end{array}$ & $\begin{array}{l}\text { (A) Resection of patent vitellointestinal } \\
\text { duct, small segment of ileum and ileoileal } \\
\text { anastomosis } \\
\text { (B) Reexploration for anastomotic leak }\end{array}$ & Death \\
\hline 7. & $5 \mathrm{mo}$ & Male & $\begin{array}{l}\text { February 19, } \\
2005\end{array}$ & $\begin{array}{l}\text { Intestinal obstruction } \\
\text { Bowel prolapse: no }\end{array}$ & $\begin{array}{l}\text { Resection of patent vitellointestinal duct, } \\
\text { small segment of ileum, and ileoileal } \\
\text { anastomosis }\end{array}$ & Well \\
\hline 8. & $2 \mathrm{mo}$ & Male & $\begin{array}{l}\text { September } \\
01,2006\end{array}$ & Fecal discharges through umbilicus & $\begin{array}{l}\text { Resection of patent vitellointestinal duct, } \\
\text { wide wedge resection of ileum, and ileal } \\
\text { repair }\end{array}$ & Well \\
\hline 9. & $3 \mathrm{mo}$ & Female & $\begin{array}{l}\text { March 01, } \\
2008\end{array}$ & Fecal discharges through umbilicus & $\begin{array}{l}\text { Resection of patent vitellointestinal duct, } \\
\text { wide wedge resection of ileum, and ileal } \\
\text { repair }\end{array}$ & Well \\
\hline 10. & $2 \mathrm{mo}$ & Female & $\begin{array}{l}\text { June 03, } \\
2010\end{array}$ & $\begin{array}{l}\text { Intestinal obstruction } \\
\text { Bowel prolapse: yes }\end{array}$ & $\begin{array}{l}\text { Resection of patent vitellointestinal duct, } \\
\text { wide wedge resection of ileum, and ileal } \\
\text { repair }\end{array}$ & Well \\
\hline 11. & $4 \mathrm{mo}$ & Male & $\begin{array}{l}\text { May 31, } \\
2011\end{array}$ & Fecal discharges through umbilicus & $\begin{array}{l}\text { Resection of patent vitellointestinal duct, } \\
\text { wide wedge resection of ileum, and ileal } \\
\text { repair }\end{array}$ & Well \\
\hline 12. & $10 \mathrm{mo}$ & Male & $\begin{array}{l}\text { August 11, } \\
2011\end{array}$ & $\begin{array}{l}\text { Intestinal obstruction } \\
\text { Bowel prolapse: yes }\end{array}$ & $\begin{array}{l}\text { Resection of patent vitellointestinal duct, } \\
\text { wide wedge resection of ileum and ileal } \\
\text { repair }\end{array}$ & Well \\
\hline 13. & $3 \mathrm{mo}$ & Male & $\begin{array}{l}\text { January 07, } \\
2012\end{array}$ & $\begin{array}{l}\text { Intestinal obstruction } \\
\text { Bowel prolapse: yes }\end{array}$ & $\begin{array}{l}\text { Resection of patent vitellointestinal duct, } \\
\text { wide wedge resection of ileum, and ileal } \\
\text { repair }\end{array}$ & Well \\
\hline 14. & $4 \mathrm{mo}$ & Male & $\begin{array}{l}\text { January 14, } \\
2012\end{array}$ & Fecal discharges through umbilicus & $\begin{array}{l}\text { Resection of patent vitellointestinal duct, } \\
\text { wide wedge resection of ileum, and ileal } \\
\text { repair }\end{array}$ & Well \\
\hline 15. & $15 d$ & Male & $\begin{array}{l}\text { August 08, } \\
2012\end{array}$ & $\begin{array}{l}\text { Intestinal obstruction } \\
\text { Bowel prolapse: yes }\end{array}$ & $\begin{array}{l}\text { Resection of patent vitellointestinal duct, } \\
\text { small segment of ileum, and ileoileal } \\
\text { anastomosis }\end{array}$ & Death \\
\hline 16. & $6 \mathrm{mo}$ & Male & $\begin{array}{l}\text { January 31, } \\
2013\end{array}$ & $\begin{array}{l}\text { Intestinal obstruction } \\
\text { Bowel prolapse: yes }\end{array}$ & $\begin{array}{l}\text { Resection of patent vitellointestinal duct, } \\
\text { wide wedge resection of ileum, and ileal } \\
\text { repair }\end{array}$ & Well \\
\hline 17. & $2 \mathrm{mo}$ & Male & $\begin{array}{l}\text { February 20, } \\
2014\end{array}$ & Fecal discharges through umbilicus & $\begin{array}{l}\text { Resection of patent vitellointestinal duct, } \\
\text { wide wedge resection of ileum, and ileal } \\
\text { repair }\end{array}$ & Well \\
\hline 18. & $4 \mathrm{mo}$ & Male & $\begin{array}{l}\text { June } 24, \\
2014\end{array}$ & $\begin{array}{l}\text { Intestinal obstruction } \\
\text { Bowel prolapse: yes }\end{array}$ & $\begin{array}{l}\text { Resection of patent vitellointestinal duct, } \\
\text { small segment of ileum, and ileoileal } \\
\text { anastomosis }\end{array}$ & Well \\
\hline
\end{tabular}


Table 1 (continued)

\begin{tabular}{|c|c|c|c|c|c|c|}
\hline $\begin{array}{l}\text { Serial } \\
\text { no. }\end{array}$ & Age & Sex & $\begin{array}{l}\text { Date of } \\
\text { operation }\end{array}$ & $\begin{array}{l}\text { Presentation and clinical } \\
\text { examination }\end{array}$ & Operative procedures executed & Result \\
\hline 19. & $45 d$ & Male & $\begin{array}{l}\text { October 29, } \\
2015\end{array}$ & Fecal discharges through umbilicus & $\begin{array}{l}\text { Resection of patent vitellointestinal duct, } \\
\text { wide wedge resection of ileum, and ileal } \\
\text { repair }\end{array}$ & Well \\
\hline 20. & $1 \mathrm{mo}$ & Male & $\begin{array}{l}\text { November } \\
03,2015\end{array}$ & $\begin{array}{l}\text { Intestinal obstruction } \\
\text { Bowel prolapse: yes } \\
\text { Bowel gangrene: yes }\end{array}$ & $\begin{array}{l}\text { Resection of patent vitellointestinal duct, } \\
\text { small segment of ileum and ileoileal } \\
\text { anastomosis }\end{array}$ & Well \\
\hline 21. & $1 \mathrm{mo}$ & Female & $\begin{array}{l}\text { February 02, } \\
2017\end{array}$ & Fecal discharges through umbilicus & $\begin{array}{l}\text { Resection of patent vitellointestinal duct, } \\
\text { wide wedge resection of ileum, and ileal } \\
\text { repair }\end{array}$ & Well \\
\hline 22. & $7 \mathrm{~d}$ & Male & $\begin{array}{l}\text { February 28, } \\
2018\end{array}$ & $\begin{array}{l}\text { Intestinal obstruction } \\
\text { Bowel prolapse: yes } \\
\text { Bowel gangrene: yes }\end{array}$ & $\begin{array}{l}\text { Resection of patent vitellointestinal duct, } \\
\text { segment of ileum, and an ileostomy }\end{array}$ & Well \\
\hline 23. & $15 d$ & Male & $\begin{array}{l}\text { November } \\
26,2019\end{array}$ & Fecal discharges through umbilicus & $\begin{array}{l}\text { Resection of patent vitellointestinal duct, } \\
\text { wide wedge resection of ileum, and ileal } \\
\text { repair }\end{array}$ & Well \\
\hline 24. & $1 \mathrm{mo}$ & Male & $\begin{array}{l}\text { December } \\
24,2019\end{array}$ & $\begin{array}{l}\text { Intestinal obstruction } \\
\text { Bowel prolapse: yes } \\
\text { Bowel gangrene: yes }\end{array}$ & $\begin{array}{l}\text { Resection of patent vitellointestinal duct, } \\
\text { segment of ileum, and an ileostomy }\end{array}$ & Well \\
\hline
\end{tabular}

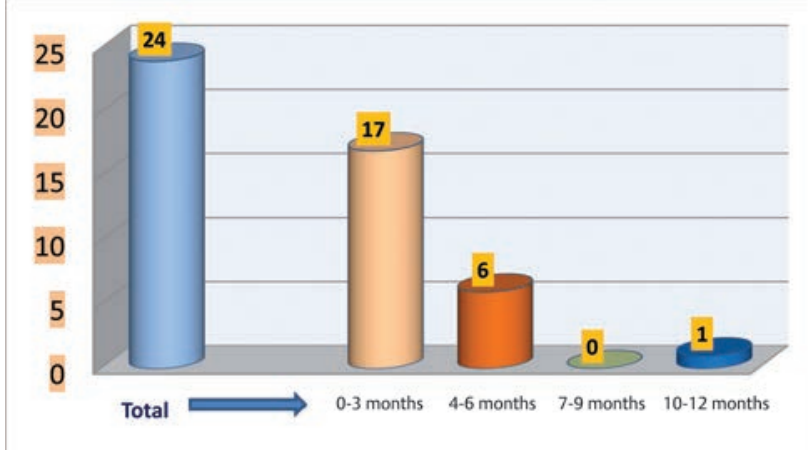

Fig. 1 Age distribution of infants operated for the patent vitellointestinal duct.
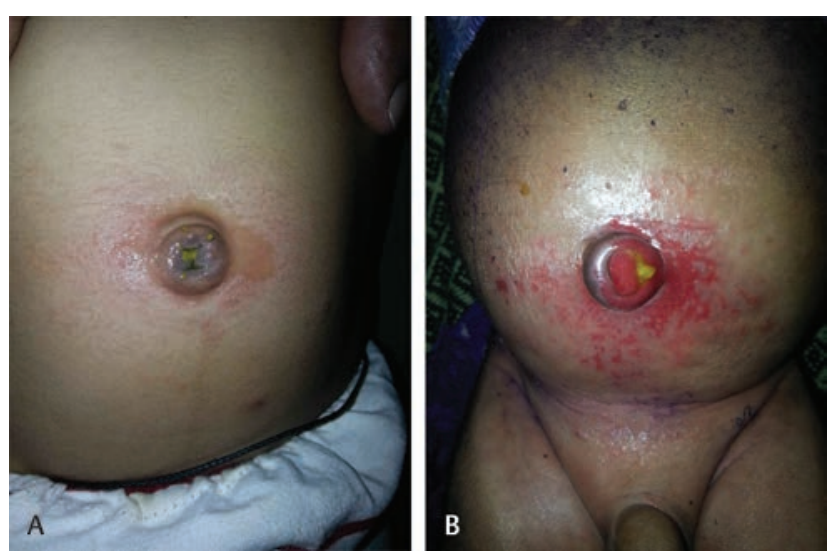

Fig 2 (A) Photograph of an infant showing fecal discharge through the umbilicus without periumbilical redness/skin excoriation. (B) Photograph of an infant showing fecal discharge through the umbilicus with periumbilical redness and skin excoriation.

Yamada et al in a review of Japanese literature observed that 28 cases had prolapsed bowel amongst 53 cases of patent vitellointestinal duct. ${ }^{6}$ In Kirtland, in a review of 131 documented cases of patent vitellointestinal duct, 28 of them had prolapsed bowel. ${ }^{11}$ Present report of patent vitellointestinal ducts also documented that $50 \%$ of the infants had prolapsed bowel. Prolapse of the bowel through the umbilicus is probably related to the luminal diameter of the patent vitellointestinal duct. Author strongly believe that the wider the lumen of the patent vitellointestinal duct, the more the chances of the bowel prolapse, but smaller lumen size does not guarantee that there would not be a bowel prolapse.

There are two options for the surgical resection of the patent vitellointestinal duct: (1) resection of the patent vitellointestinal duct along with wide wedge resection of the ileum and ileal repair; and (2) resection of the patent vitellointestinal duct, adjacent small segment of ileum, and ileoileal anastomosis. ${ }^{6-8,10,13,17}$ Above surgical procedures can be accomplished through the subumbilical incision, infraumbilical incision, transumbilical approach, or supraumbilical right transverse abdominal incisions. Surgical procedures done through the umbilicus and subumbilical incision carries the best cosmetic results. Resection of the patent vitellointestinal duct along with wide wedge resection of the ileum and ileal repair is feasible in many of the cases of patent vitellointestinal duct. In this technique, there are chances of ectopic mucosa that may be left behind in native ileum. ${ }^{7}$ Therefore resection of the patent vitellointestinal duct, small segment of ileum and ileoileal anastomosis is a better option. ${ }^{7}$ The timing of surgical resection of the patent vitellointestinal duct is very crucial. Most of the authors suggested an early surgical intervention to prevent morbidity in the form of bowel prolapse and intestinal obstruction.

Postoperative complications may occur following the surgical procedures done for the resection of the patent vitellointestinal duct and are anastomotic leak, septicemia, 

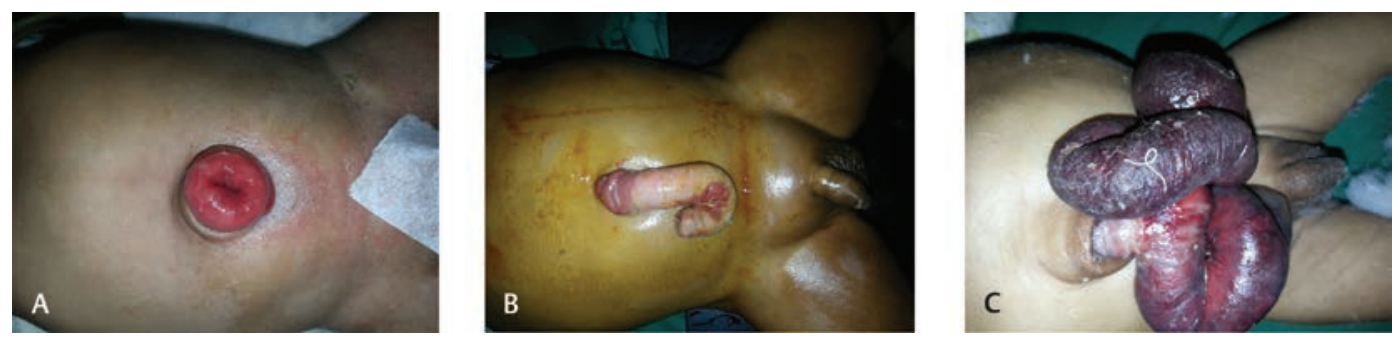

Fig 3 (A) Photograph of an infant showing prolapsed of bowel mucosa through the umbilicus. (B) Photograph of an infant showing prolapsed ileum (without gangrene) through the umbilicus. (C) Photograph of an infant showing prolapsed ileum (with gangrene) through the umbilicus.

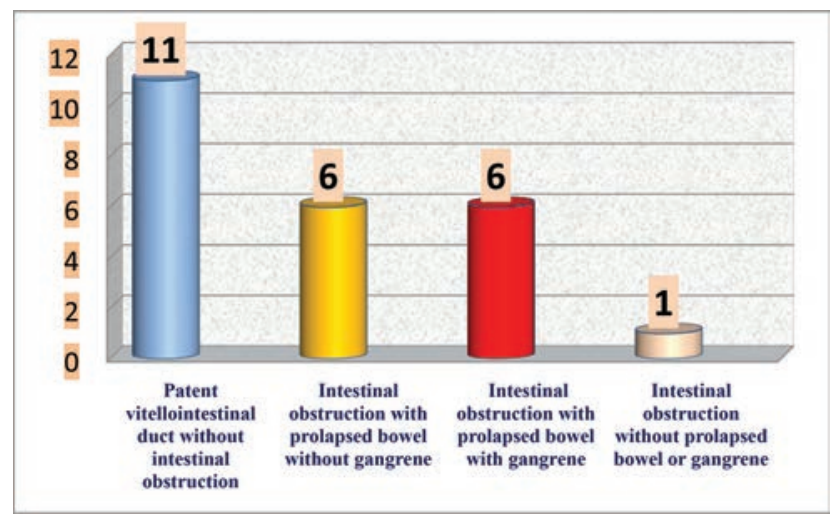

Fig. 4 Operative findings in infants with the patent vitellointestinal duct.

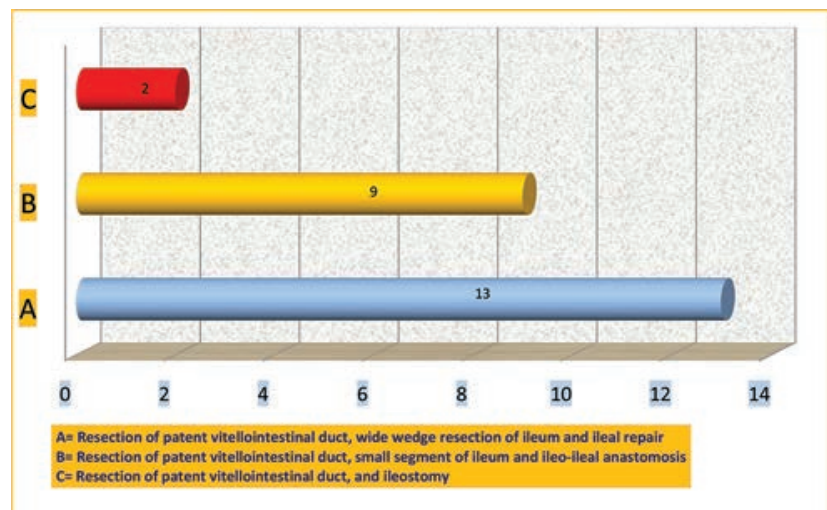

Fig. 5 Operative procedures executed in infants for the patent vitellointestinal duct.

peritonitis, and postoperative intestinal obstruction/ adhesion. ${ }^{6,8,11}$ Mortality has also been reported following the surgical procedures done for the patent vitellointestinal duct and documented more in children who had prolapsed bowel. ${ }^{6,8,11}$ There were two (8.3\%) deaths in present study, and both of the infants had major postoperative complications.

\section{Conclusion}

Patent vitellointestinal ducts not only present with fecal discharges through the umbilicus but also present with prolapsed bowel and features of acute small bowel obstruction in as many as $50 \%$ of the cases. Patent vitellointestinal duct should be excised at the earliest, as delay in seeking treatment was associated with considerable morbidity and mortality. Surgical resection of the patent vitellointestinal duct along with small segment of ileum and ileoileal anastomosis is preferable over wide-wedge resection of ileum and ileal repair.

\section{Note}

This study was presented at Paediatric Surgeons Club in Bhopal on September 21, 2019.

\section{Conflict of Interest}

None declared.

\section{References}

1 Mullassery D, Losty PD, Omphalomesenteric duct remnants. In: Puri P, Höllwarth M, eds. Pediatric Surgery: Diagnosis and Management. Berlin, Germany: Springer; 2009 491-496

2 Campbell BT, Meckel's diverticulum and other omphalomesenteric duct remnants. In: Wyllie R, Hyams JS, eds. Pediatric Gastrointestinal and Liver Disease. 4th ed. Philadelphia, PA: Elsevier-Saunders; 2011 572-575

3 Snyder CL, Meckel Diverticulum. In: Coran AG, Adzick NS, Krummel TM, et al., eds. Pediatric Surgery 7th Ed. Philadelphia, PA: Elsevier-Saunders; 2012 1085-1092

4 Sagar J, Kumar V, Shah DK. Meckel's diverticulum: a systematic review. J R Soc Med 2006;99(10):501-505

5 Hansen CC, Søreide K. Systematic review of epidemiology, presentation, and management of Meckel's diverticulum in the 21st century. Medicine (Baltimore) 2018;97(35):e12154

6 Yamada T, Seiki Y, Ueda M, et al. Patent omphalomesenteric duct: a case report and review of Japanese literature. Asia Oceania J Obstet Gynaecol 1989;15(3):229-236

7 Kadian YS, Verma A, Rattan KN, Kajal P. Vitellointestinal duct anomalies in infancy. J Neonatal Surg 2016;5(3):30

8 Ameh EA, Mshelbwala PM, Dauda MM, Sabiu L, Nmadu PT. Symptomatic vitelline duct anomalies in children. S Afr J Surg 2005;43(3):84-85

9 Alevli F, Akbulut S, Dolek Y, Cakabay B, Sezgın A. Patent vitelline duct as a cause of acute abdomen: case report of an adult patient. Turk J Gastroenterol 2011;22(1):101-103

10 Celebi S, Ozaydin S, Polat E, Basdas C, Alim ER, Sander S. Vitelline duct pathologies in neonates. North Clin Istanb 2018;5(3):211-215

11 Aitken J. Remnants of the vitello-intestinal duct; a clinical analysis of 88 cases. Arch Dis Child 1953;28(137):1-7

12 Brown KL, Glover DM. Persistent omphalomesenteric duct; incidence relative to Meckel's diverticulum. Am J Surg 1952;83(5):680-685

13 Choi JY, Jung PM. A clinical study of vitelline duct and vessel remnants. J Korean Assoc Pediatr Surg 1998;4(1):27-33 
14 Pintér A, Szemlédy F, Pilaszanovich I. Remnants of vitelline duct: analysis of 66 cases. Acta Paediatr Acad Sci Hung 1978;19(2):113-123

15 Vane DW, West KW, Grosfeld JL. Vitelline duct anomalies. Experience with 217 childhood cases. Arch Surg 1987;122(5):542-547
16 Kittle CF, Jenkins HP, Dragstedt LR. Patent omphalomesenteric duct and its relation to the diverticulum of Meckel. Arch Surg 1947;54(1):10-36

17 Durakbasa CU, Okur H, Mutus HM, et al. Symptomatic omphalomesenteric duct remnants in children. Pediatr Int 2010;52(3):480-484 